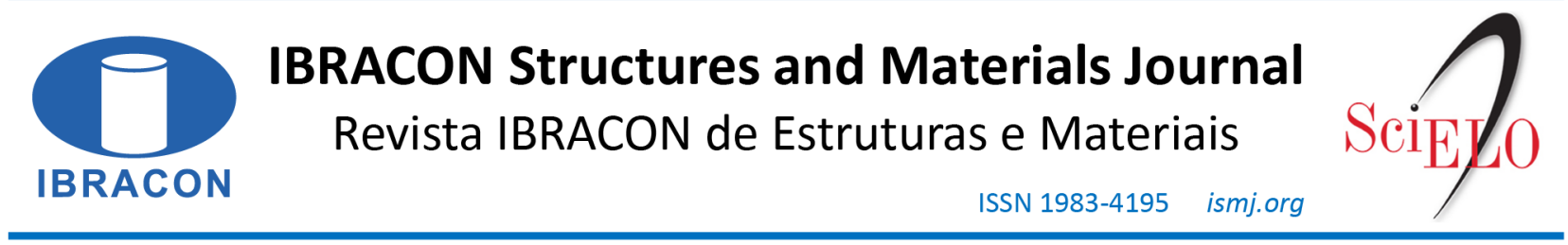

ORIGINAL ARTICLE

\title{
Temperature influence on creep of reinforced concrete
}

\section{Influência da temperatura na fluência do concreto armado}

\author{
Edmilson Lira Madureira $^{\mathrm{a}}$ \\ Brenda Vieira Costa Fontes ${ }^{\mathrm{b}}$
}

${ }^{a}$ Universidade Federal do Rio Grande do Norte - UFRN, Centro de Tecnologia, Departamento de Engenharia Civil, Natal, RN, Brasil

bUniversidade de Brasília - UnB, Departamento de Engenharia Civil e Ambiental, Programa de Pós-graduação em Estruturas e Construção Civil, Brasília, DF, Brasil

Received 25 September 2019 Accepted 17 March 2020

\begin{abstract}
The creep of concrete promotes strains over time in structural members kept under sustained load. It causes the stress decrease on the concrete and the steel stress increase in reinforced concrete members. The moisture content and temperature influence significantly such phenomenon. The creep strains model of the NBR 6118/2014 [1] is, applicable, solely, to those cases of constant stress magnitudes. Reinforced concrete members exhibit variations on the stress magnitudes and, in this way, requires the use of an alternative model for the prediction of the creep strains as the so known the State Model. This report refers itself to temperature influence analysis upon creep strains of reinforced concrete structural members. The results have revealed that temperature speeds up the creep effects and, in this way, the steel yielding caused by the stress increase on the reinforcement bars occurs at earlier ages.
\end{abstract}

Keywords: reinforced concrete, thin-walled column, creep, modelling, temperature.

Resumo: A Fluência do concreto promove deformações com o tempo em membros estruturais mantidos carregados permanentemente. Ela causa a redução das tensões no concreto e o aumento das tensões no aço em membros de concreto armado. A umidade e a temperatura influenciam significativamente a Fluência. O modelo de deformações por Fluência da NBR 6118/2014 [1] é, aplicável, apenas, aos casos de tensões constantes. Em membros de concreto armado as tensões variam exigindo o uso de modelo alternativo de cálculo de suas deformações a exemplo do modelo de estado. Este relato refere-se à análise da influência da temperatura na Fluência de membros estruturais de concreto armado. Os resultados revelaram que a temperatura acelera os efeitos de fluência e, assim, o escoamento do aço mediante o aumento de tensões nas barras da armadura ocorre precocemente.

Palavras-chave: concreto armado, pilares parede, fluência, modelagem, temperatura.

How to cite: E. L. Madureira and B. V. C. Fontes, “Temperature Influence on Creep of Reinforced Concrete”, Rev. IBRACON Estrut. Mater., vol. 13 , no. 6, e13601, 2020, https://doi.org/10.1590/S1983-41952020000600001

\section{INTRODUCTION}

The progressive strains over time developed on concrete structural members maintained under sustained load characterize the phenomenon known as material creep [1].

The creep strains are associated, mainly, to the viscous mechanical behavior of certain water coating that remains adsorbed at the surfaces of the cement Portland grains, inner to the sound concrete, even at high thermal levels [2].

Among the several relevant factors that influence the creep deformation they may be included the moisture content, the stresses field, the concrete strength, the reinforcement ratio and temperature [1].

The creep strains modify, significantly, the stresses fields in reinforced concrete members since they can promote the stresses reduction on the mass of the concrete and its increase in the reinforcement steel bars, which can induce those latter to the development of the yielding phenomenon [3]. It is known, including, that temperature speeds up the creep effects rates [1]. 
The creep of concrete numerical model recommended by the NBR 6118/2014 standard [4] is based on the traditional creep coefficient concept and, in this way, is applicable, directly, overall, to that cases for which the stress magnitudes upon the solid mass constituted of the referring material maintain itself unchanged over the phenomenon progress. Nevertheless, the calculus framework presented in that way may be modified to an alternative mode becoming it able to its application on those cases for which occur stress magnitude variations as, for instance, to creep strains analyses involving reinforced concrete structural members. The formulation of such a model depends on the adoption of simplified artifices from which result the Memory Models, that are named in this way, because they demand, in their application, the history of stresses storage [5]. The referring storage amount promotes a large-scale computational effort becoming the modelling unfeasible [6]. In order to overcome the difficulties related to such a computational memory storage, some models were developed from the integrating scheme changing, that provide the use, exclusively, of the stresses at the discrete instant of time previous to the one that is being considered. For that reason, such advanced formulation received the State Models designation [5].

The aim of this work is the numerical simulation analysis of the temperature effects on creep of Portland cement concrete based on a State Model, highlighting, above all, its consequences on the mechanical performance of reinforced concrete structural members.

The subjects of this paper are accomplished from the numerical analysis of thin walled columns presenting certain physical properties and loading condition and a diversity of thermal levels and moisture contents.

The expected results by this work is the better knowing with respect to the fashion from which the temperature effect upon the creep phenomenon influences the overall mechanical performance of reinforced concrete structural specimens.

The main scientific contribution of this product is to provide numerical results involving the repercussion of the creep, at a diversity of thermal levels, on the mechanical performance of reinforced concrete structural members, to the technical literature, considering that such kind of data are even scarcer.

\section{MODELLING}

The approximation from quadratic isoparametric formulation was adopted in the present analysis work.

\subsection{Concrete Response to Loading}

The plane state of stress orthotropic nonlinear framework proposed by Kwak and Filippou [7], upon an incremental iterative procedure and the finite element approach, were adopted in this work. In this way, the constitutive matrix elements were defined in a similar way to that one applied to the uniaxial state of stresses, taking as a reference, in its turn, the equivalent strains "Eei", that are given for every principal directions by Equation 1.

$\varepsilon_{e i}=\varepsilon_{i}+D_{i j} \varepsilon_{j} / D_{i i}$

The "il" and " $\mathbf{j}$ " indexes refer to the principal plan directions. The "D $\mathbf{D}_{\mathrm{ij}}$ " coefficients represent the constitutive matrix elements.

The concrete compressive mechanical performance was simulated from the constitutive relationships proposed by Hognestad [8], expressed in the form of Equation 2.

$\sigma_{i}=\frac{2 \sigma_{i p}}{\varepsilon_{i p}}\left(1-\frac{\varepsilon_{e i}}{2 \varepsilon_{i p}}\right) \varepsilon_{e i}, \quad$ for $\varepsilon_{i p}<\varepsilon_{e i}<0$

The " $\sigma_{\mathrm{ip}}$ " and " $\varepsilon_{\mathrm{ip}}$ " parameters represent the concrete peak stress and its corresponding strain, respectively, beyond every principal direction namely "i". The "Ecu" parameter, in turn, is the concrete ultimate strain in uniaxial compression. Equation 2 represents the hardening branch $\mathbf{O A}$ over the curve of Figure 1. 


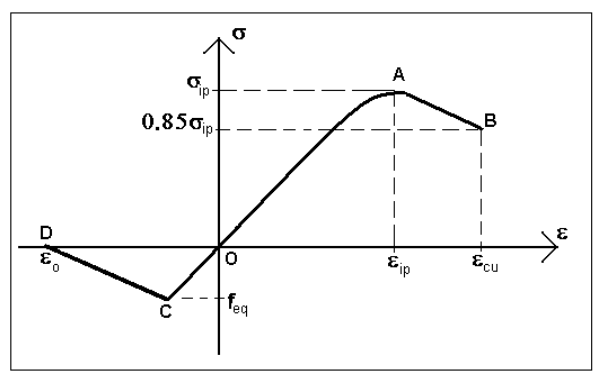

Figure 1. Stress strain curve for the concrete.

The concrete secant modulus recommended by [4] was adopted, that is expressed from Equation 3.

$E_{c s}=0.85 \times 5600 \sqrt{f_{c k}}=4760 \sqrt{f_{c k}}$

Such that the "f $\mathbf{f}_{\text {ck" }}$ " parameter represents the concrete uniaxial compressive strength.

The concrete ultimate stresses were defined from the failure envelope proposed by Kupfer and Gerstle [9], Figure 2, whose analytical version in biaxial compression state is in Equation 4.

$\left(\beta_{1}+\beta_{2}\right)^{2}-\beta_{2}-3.65 \beta_{1}=0$

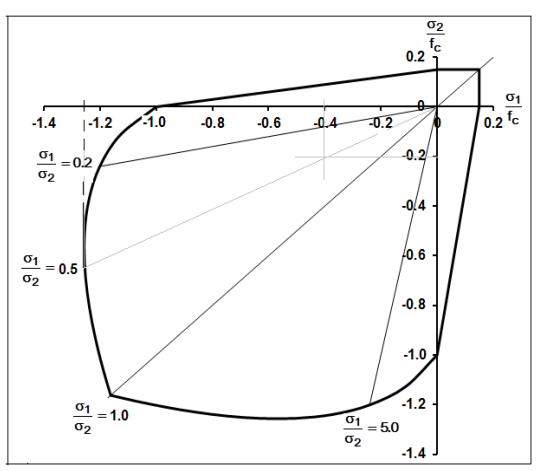

Figure 2. Ultimate Stress Envelop for concrete in biaxial state of stresses.

For which $\boldsymbol{\beta}_{\mathbf{i}}=\boldsymbol{\sigma}_{\mathbf{i p}} / \mathbf{f}_{\text {ck. }}$. If $\alpha=\sigma_{1} / \sigma_{2}$, where the $\sigma_{1}$ and $\sigma_{2}$ are the principal stresses magnitudes such that $0>\sigma_{1}>\sigma_{2}$, from Equation 4 results in Equation 5.

$\sigma_{2 c}=\frac{1+3.65 \alpha}{(1+\alpha)^{2}} f_{c k}$ and $\sigma_{l c}=\alpha \sigma_{2 c}$

The strains related to peak stresses in biaxial compression state, " $\varepsilon_{2}$ " and " $\boldsymbol{\varepsilon}_{1}$ ", according to [7], are obtained from Equation 6.

$\varepsilon_{2 p}=\varepsilon_{c o}\left(3 \beta_{2}-2\right)$ and $\varepsilon_{l p}=\varepsilon_{c o}\left(-1.6 \beta_{I}^{3}+2.25 \beta_{I}^{2}+0.35 \beta_{1}\right)$

In which the " $\varepsilon \mathrm{co}$ " parameter is the deformation corresponding to the compressive peak stress referring to uniaxial state of stresses. 
The concrete mechanical behavior referring to biaxial state of stresses was modelled from the incremental constitutive relationship proposed by Desai and Siriwardance [1]:

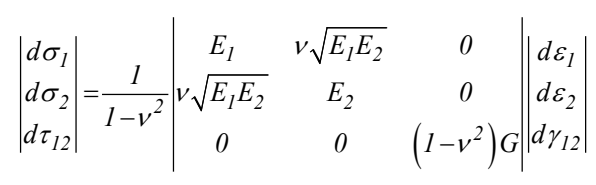

The differentiations, " $\mathrm{d} \sigma_{1}$ ", " $\mathrm{d} \sigma_{2}$ " e " $\mathrm{d} \tau_{12}$ ", on Equation 7, represent the stress increments on the principal directions. The " $\mathbf{E}_{\mathbf{i}}$ 's" parameters are the concrete deformation modules relating to such directions and " $\boldsymbol{v}$ " is the concrete Poisson's ratio. The "G" parameter, namely, the concrete transverse deformation module, may be expressed by the relationship in Equation 8.

$\left(1-v^{2}\right) G=0.25\left(E_{1}+E_{2}\right)-2 v \sqrt{E_{1} E_{2}}$

The eight-nodded plane quadrilateral elements $\mathbf{Q 8}$ were performed to represent the mass of concrete region, Figure 3a.

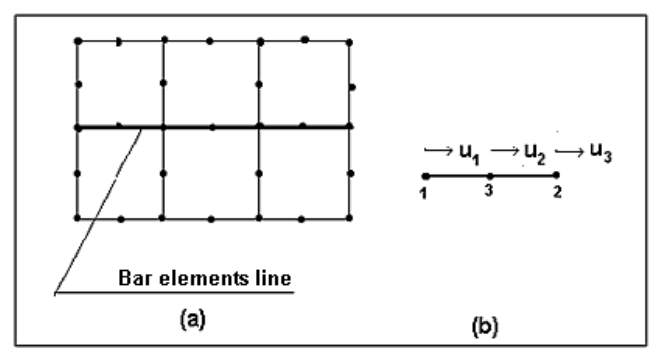

Figure 3. Finite elements: a) Plane Q8; b) bar L3.

\subsection{Steel Response to Loading}

The steel of the reinforcement was considered as an elastic perfectly plastic material. Due to the great reinforcement steel bars transverse flexibility, only its axial stiffness is taken in account in its mechanical performance, and then, they are simulated as three-nodded bar elements $\mathbf{L 3}$, Figure 3b. In this way, the referring stiffness matrix "K" is regarded according Equation 9.

$K=\frac{2 E_{s} A_{s}}{L}\left[\begin{array}{rrr}1 & 0 & -1 \\ 0 & 1 & -1 \\ -1 & -1 & 2\end{array}\right]$

where the "Es" parameter represents the steel Young's modulus, which is considered equal to 210 GPa. "As" is the reinforcement cross sectional area, while "L" represents the bar finite element length.

\subsection{Creep Strains}

The creep strains are simulated from the state model proposed by Kawano and Warner [5], Equation 10.

$\varepsilon_{c}(t)=\varepsilon_{c d}(t)+\varepsilon_{c v}(t)$

Where " $\varepsilon_{\mathrm{cd}}(\mathbf{t})$ " and " $\boldsymbol{\varepsilon}_{\mathrm{cv}}(\mathbf{t})$ " are the deformation parcels due to hardening and visco-elastic effects, respectively, such that: 
$\varepsilon_{c d}(t)=-\frac{1}{E_{0}} \int_{0}^{t} \frac{d \Phi_{d}(t, \tau)}{d \tau} \sigma(\tau) d \tau$ and $\varepsilon_{c v}(t)=-\frac{1}{E_{0}} \int_{0}^{t} \frac{d \Phi_{v}(t, \tau)}{d \tau} \sigma(\tau) d \tau$

In Equation 11, the " $\phi_{\mathbf{d}}(\mathbf{t}, \boldsymbol{\tau})$ " and " $\phi_{\mathbf{v}}(\mathbf{t}, \boldsymbol{\tau})$ " functions represent their respective creep coefficients. In their incremental versions, these parcels are presented from Equation 12 and Equation 13.

$\Delta \varepsilon_{c d}\left(t_{n}\right)=\frac{\sigma\left(t_{n-1}\right)}{E_{o}}\left[\Phi_{d}\left(t_{n}, t_{o}\right)-\Phi_{d}\left(t_{n-1}, t_{o}\right)\right]$

and,

$\Delta \varepsilon_{c v}\left(t_{n}\right)=\left[\frac{\Phi_{v}^{*} \sigma\left(t_{n-1}\right)}{E_{o}}-\varepsilon_{c v}\left(t_{n-1}\right)\right]\left[1-e^{-\Delta t_{n} / T_{v}}\right]$

in which:

$\Phi_{d}\left(t_{n}, t_{o}\right)=\frac{\left(t_{n}-t_{o}\right)^{0.6}}{10+\left(t_{n}-t_{o}\right)^{0.6}} \Phi_{d}^{*}$

In Equation 14, " $\phi * \mathrm{~d}$ " and " $\phi{ }^{*}$ " are the asymptotic creep coefficients referring to those two parcels, and " $\mathbf{T}_{\mathrm{v}}$ " is the retardation time. The " $t_{n}$ " parameter is the instant of time for which the creep deformations are being calculated, " $t_{n-1}$ " is the discrete instant, immediately preceding the instant " $t_{n}$ ", and " $t_{0}$ " is the concrete age at the instant of loading. At every instant " $\mathbf{n}_{\mathbf{n}}$ " the creep strains are described according to Equation 15.

$\varepsilon_{c}\left(t_{n}\right)=\varepsilon_{c}\left(t_{n-1}\right)+\Delta \varepsilon_{c}\left(t_{n}\right)$

where " $\Delta \varepsilon_{\mathrm{c}}\left(\mathrm{t}_{\mathrm{n}}\right)$ " is the incremental creep strain that is obtained from Equation 16.

$\Delta \varepsilon_{c}\left(t_{n}\right)=\Delta \varepsilon_{c d}\left(t_{n}\right)+\Delta \varepsilon_{c v}\left(t_{n}\right)$

The temperature effect upon the creep strains simulation was based on the NBR 6118/2014 proceedings [4] from which, the discrete observation time of the phenomenon must be fitted to fictitious concrete ages expressed by Equation 17.

$t_{n}=\alpha \sum_{i} \frac{T_{i}+10}{30} \Delta t_{e f, i}$

where the " $\boldsymbol{\alpha}$ " parameter is the cement hardening rate dependent coefficient, for which, the ABNT NBR 6118/2014 proceedings [[4]] recommends suitable typical values that may be applied if experimental results are not available. The " $\mathbf{T}_{\mathbf{i}}$ " parameter represents the average daily environmental temperature that is expressed in Celsius Degrees $\left({ }^{\circ} \mathrm{C}\right)$, while the " $\Delta \mathbf{t}_{\mathbf{e f}}$ " term is the elapsed time along what the average daily environmental temperature, $\mathrm{T}_{\mathrm{i}}$, may be assumed as a constant value.

It is assumed in this work that, during each time interval, the stresses magnitudes remain constant, although they may present variation over all the phenomenon observation period, according a step kind function. 


\section{COMPUTATIONAL SUPPORT}

With a view to the acquisition of the results aimed at the fulfilment of the objectives of this work, the software named "Análise Constitutiva Não-Linear" - ACNL [10] was used. Such program was structured according to incremental and iterative procedure and the Finite Elements Method (FEM), on a Nonlinear Orthotropic Formulation in plane state of stresses [7]. It even covers, in its algorithmic framework, the element formulations described in the Section 2 of this paper.

The images referring to the displacement fields were generated from the application NLPOS [11] while those corresponding to the stress fields were produced from the application PROJECT2, elaborated in DELPH 10.2 [12].

\section{COMPUTATIONAL CODE VALIDATION}

The adopted Code as the Computational Support for this paper was applied to perform the analysis of a rectangular crosssectional concrete thin-walled column $3.00 \mathrm{~m}$ height, $0.20 \mathrm{~m}$ thick and $1.20 \mathrm{~m}$ width, in plane state of stresses, Figure 4, whose concrete slump test abatement was fixed from $0 \mathrm{~cm}$ up to $4 \mathrm{~cm}$ and the moisture content in $40 \%$. It was considered two cases for which the reinforcement ratios were fixed as $0.63 \%$ and $1.58 \%$. The results of such analysis were compared with their corresponding values obtained from a simplified model, based on the Solid Mechanic Postulates, under uniaxial state of stresses, as performed by Madureira at al [13]. The obtained results showed a good agreement, Figure 5.

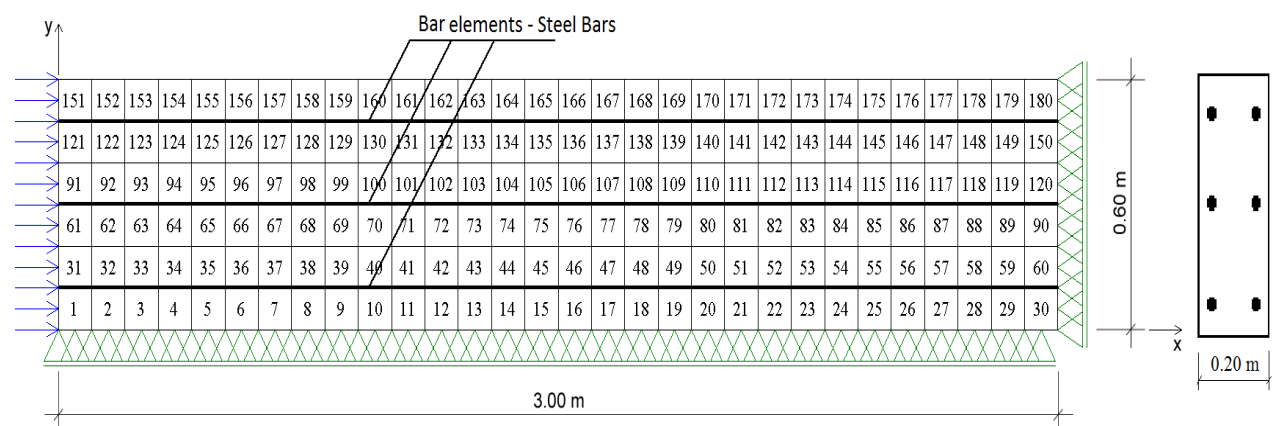

Figure 4. Basic model, Problem domain and finite element mesh.

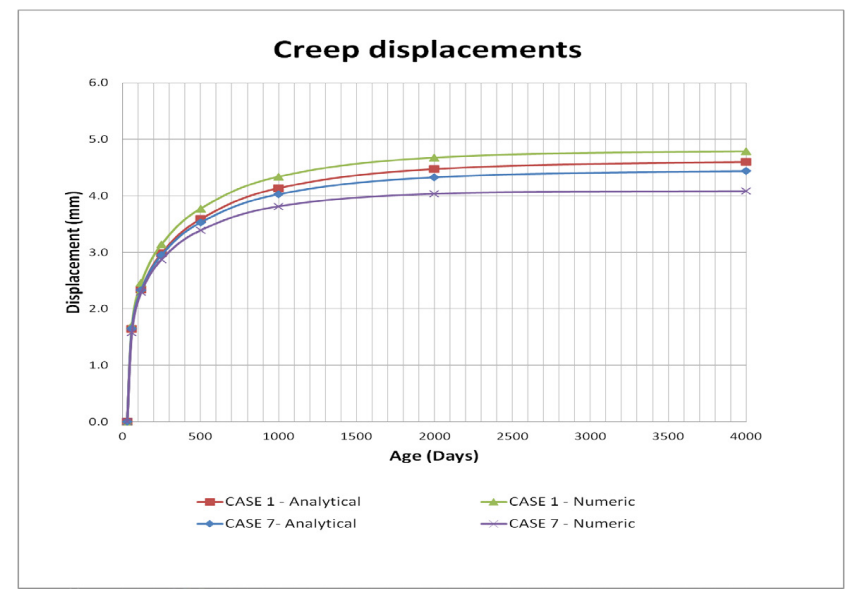

Figure 5. Creep displacements by time curves.

\section{ANALYSED MODELS}

The studied models are rectangular cross-sectional concrete thin-walled column, $3.00 \mathrm{~m}$ height, $0.20 \mathrm{~m}$ thick and $1.20 \mathrm{~m}$ width, cast both in $\mathbf{C 3 0}$ or in $\mathbf{C 4 0}$ concrete, reinforced by $\mathbf{C A - 5 0}$ steel bars, Figure 4.

The structural members are subjected to a uniform load that is distributed on the column top section, whose magnitude progresses on a gradual mode from zero up to a final value fixed at $3750 \mathrm{kN}$ and $4980 \mathrm{kN}$, for C30 and C40 
concrete cases, respectively, promoting stresses whose magnitude are about $40 \%$ of the concrete ultimate compressive stress, the concrete $\mathbf{f}_{\text {ck, }}$, Table 1 . Such load magnitudes are chosen under that pattern as a purpose to regard the NBR 6118/2014 proceedings creep model stresses limitation [4].

Table 1. Studied cases characterization.

\begin{tabular}{ccccc}
\hline Cases & $\mathbf{f}_{\mathbf{c k}}(\mathbf{M P a})$ & Temperature $\left({ }^{\circ} \mathbf{C}\right)$ & Moisture Content $\mathbf{( \% )}$ & $\Phi_{v}^{*}$ \\
\hline 1 & 30 & 20 & 40 & 1.63 \\
\hline 2 & 30 & 40 & 40 & 1.63 \\
\hline 3 & 30 & 60 & 40 & 1.63 \\
\hline 4 & 30 & 80 & 40 & 1.63 \\
\hline 5 & 30 & 100 & 40 & 1.63 \\
\hline 6 & 30 & 20 & 60 & 0.92 \\
\hline 7 & 30 & 40 & 60 & 0.92 \\
\hline 8 & 30 & 60 & 60 & 0.92 \\
\hline 9 & 30 & 80 & 60 & 0.92 \\
\hline 10 & 30 & 100 & 60 & 0.92 \\
\hline 11 & 40 & 40 & 40 & 1.63 \\
\hline 12 & 40 & 60 & 40 & 1.63 \\
\hline 13 & 40 & 80 & 40 & 1.63 \\
\hline 14 & 40 & 100 & 40 & 1.63 \\
\hline 15 & 40 & 20 & 40 & 1.63 \\
\hline 16 & 40 & 40 & 60 & 0.92 \\
\hline 17 & 40 & 60 & 60 & 0.92 \\
\hline 18 & 40 & 80 & 60 & 0.92 \\
\hline 19 & 40 & 100 & 60 & 0.92 \\
\hline 20 & 40 & & 60 & 0.92 \\
\hline
\end{tabular}

The analysis was performed upon twenty cases, differentiated among themselves by the concrete compressive strength, by the temperature and by the moisture content, as shown in columns 2,3 and 4 , respectively, of Table 1 . It should be emphasized that the temperature levels were chosen in this way to simulate the predominant environmental conditions around the column surface during each season of the year.

Due to the column symmetry in terms of geometry, load, strains and stresses, along the column width the problem domain was defined from the rectangular area whose horizontal dimension is equal to the column height, and the vertical dimension is equal to its half width, Figure 4. In other words, the column width is represented by its half width. Its discretization was based on the plane and bar elements, both $0.10 \mathrm{~m}$ lengths, from which resulted the mesh composed by 180 plane elements and 90 bar elements, Figure 4 . It is observed that in all column figures the structural member is being represented with its longitudinal axis coinciding with the " $x$ " direction.

The age of the concrete at the instant of loading was set as 30 days. It was assumed that the overall column perimeter surface is exposed to the environment medium. The retardation time was fixed as $\mathrm{T}_{\mathrm{V}}=600$ days. The asymptotic hardening creep coefficient was considered as being $\phi_{\mathrm{d}} *=2.0$, as recommended by Kawano and Warner [5]. The asymptotic creep coefficient referring to viscous elastic effects, $\phi_{v}{ }^{*}$, exhibit distinct values, case to case, as shown on Table 1, column 5, that is obtained by the difference between the total asymptotic creep coefficient of NBR 6118/2014 [4] and the asymptotic hardening creep coefficient.

The analysis was performed according to the "Plane State of Stresses".

For the purposes of covering the creep phenomenon longevity, the maximum age limit of concrete was set as 2000 days, which corresponds to the age from which the creep displacements, virtually, stabilizes, Figure 5. Such an elapsed time was discretized from observation instants at 33, 39, 54, 90, 176, 379, 860 and 2000 days.

\section{RESULTS AND DISCUSSION}

According to the obtained results the fields of displacements and normal stresses took the morphologies shown in Figures 6 and 7, respectively, for the equilibrium configuration at the instant of loading. For those cases corresponding to $\mathrm{C} 30$ concrete the displacement magnitude at the column top and the stress on the mass of concrete, were about $2.0 \mathrm{~mm}$ and $15 \mathrm{MPa}$, respectively, for those one referring to $\mathrm{C} 40$ concrete such parameters have assumed magnitudes about $2.4 \mathrm{~mm}$ and $20 \mathrm{MPa}$, respectively, Table 2 and 3. 


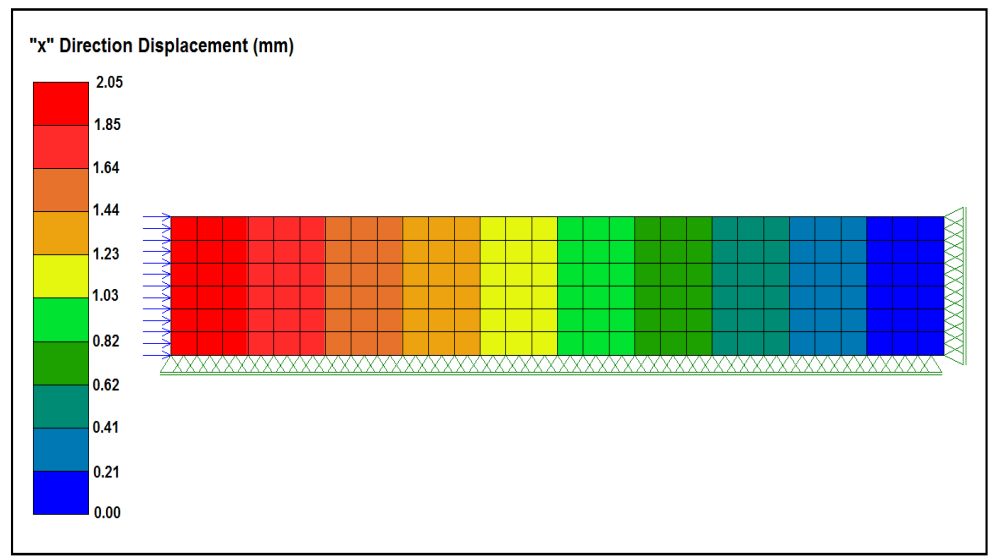

Figure 6. Field of axial displacement at the instant of loading - Case 1.

Table 2. Column top displacements.

\begin{tabular}{|c|c|c|c|c|}
\hline \multirow{2}{*}{ Cases } & \multicolumn{3}{|c|}{ Displacement (mm) } & \multirow{2}{*}{ Final age (days) } \\
\hline & Immediate & Creep (90 days) & Final creep & \\
\hline 1 & 2.05 & 2.26 & 5.14 & 860 \\
\hline 2 & 2.05 & 2.70 & 4.69 & 379 \\
\hline 3 & 2.05 & 3.02 & 5.10 & 379 \\
\hline 4 & 2.05 & 3.29 & 4.34 & 176 \\
\hline 5 & 2.05 & 3.51 & 4.60 & 176 \\
\hline 6 & 2.05 & 2.14 & 4.70 & 2000 \\
\hline 7 & 2.05 & 2.50 & 4.80 & 2000 \\
\hline 8 & 2.05 & 2.76 & 4.83 & 2000 \\
\hline 9 & 2.05 & 2.96 & 4.85 & 2000 \\
\hline 10 & 2.05 & 3.13 & 4.86 & 2000 \\
\hline 11 & 2.37 & 2.64 & 4.76 & 379 \\
\hline 12 & 2.37 & 3.16 & 4.23 & 176 \\
\hline 13 & 2.37 & 3.54 & 4.72 & 176 \\
\hline 14 & 2.37 & 3.85 & 3.85 & 90 \\
\hline 15 & 2.37 & 4.11 & 4.11 & 90 \\
\hline 16 & 2.37 & 2.50 & 4.10 & 379 \\
\hline 17 & 2.37 & 2.93 & 4.63 & 379 \\
\hline 18 & 2.37 & 3.23 & 4.09 & 176 \\
\hline 19 & 2.37 & 3.47 & 4.35 & 176 \\
\hline 20 & 2.37 & 3.66 & 4.56 & 176 \\
\hline
\end{tabular}

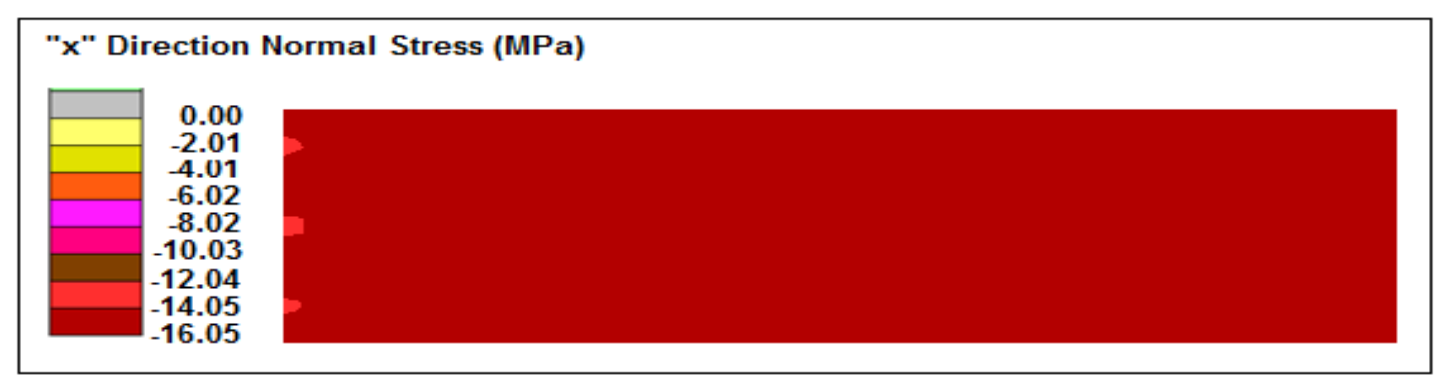

Figure 7. Field of normal stresses at the instant of loading - Case 1. 
Table 3. Stresses on the mass of concrete.

\begin{tabular}{ccccc}
\hline \multirow{2}{*}{ Cases } & & Concrete Stress (MPa) & \multicolumn{2}{c}{ Final age (days) } \\
\cline { 2 - 4 } & Immediate & Creep (90 days) & Final & 860 \\
\hline 1 & 14.8 & 14.1 & 13.0 & 379 \\
\hline 3 & 14.8 & 13.9 & 13.2 & 379 \\
\hline 4 & 14.8 & 13.8 & 13.0 & 176 \\
\hline 5 & 14.8 & 13.7 & 13.3 & 176 \\
\hline 6 & 14.8 & 13.6 & 13.2 & 2000 \\
\hline 7 & 14.8 & 14.1 & 12.9 & 2000 \\
\hline 8 & 14.8 & 14.0 & 12.7 & 2000 \\
\hline 9 & 14.8 & 13.9 & 12.7 & 2000 \\
\hline 10 & 14.8 & 13.8 & 12.7 & 2000 \\
\hline 11 & 14.8 & 13.7 & 18.2 & 379 \\
\hline 12 & 19.8 & 18.9 & 18.4 & 176 \\
\hline 13 & 19.8 & 18.8 & 18.2 & 176 \\
\hline 14 & 19.8 & 18.6 & 18.5 & 90 \\
\hline 15 & 19.8 & 18.5 & 18.4 & 90 \\
\hline 17 & 19.8 & 18.4 & 18.1 & 379 \\
\hline 18 & 19.8 & 19.0 & 18.3 & 379 \\
\hline 19 & 19.8 & 18.8 & 18.2 & 176 \\
\hline 20 & 19.8 & 18.7 & 18.2 & 176 \\
\hline
\end{tabular}

At the instant of loading, the fields of stresses, Figure 7, have presented discrete stress changing, however, at the cross sections over the vicinity of the column top, namely, the loading introduction region, it may be observed tenuous disturbances.

The acquired results have revealed that the creep strains by time evolved according the curves showed in Figures 8 and 9 and the corresponding fields have stabilized themselves according the fashions of the Figures 10 and 11.

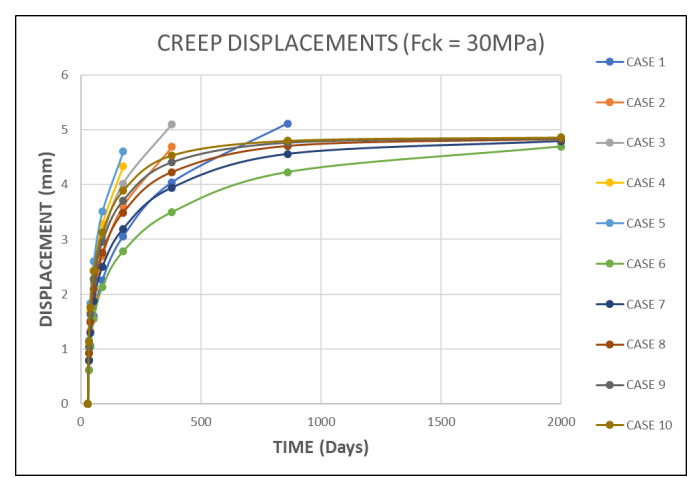

Figure 8. C30 concrete creep displacement curves.

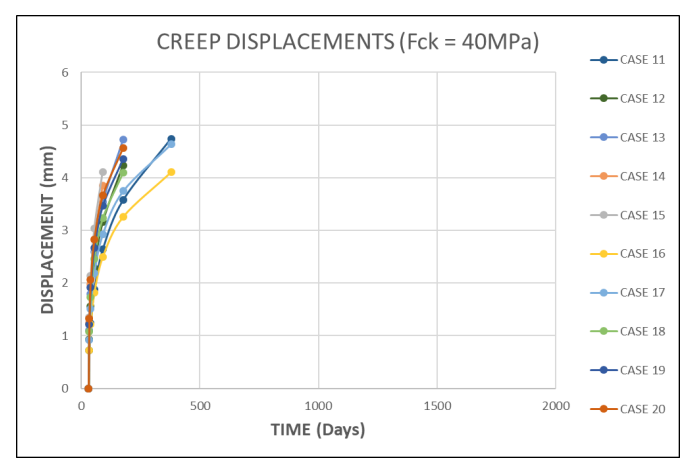

Figure 9. C40 concrete creep displacement curves. 
As a result of the creep effect the stresses on the reinforcement steel bars evolved according the curves of Figures 12 and 13 , noting up the increase occurrence in their magnitude. For every case associated to $\mathrm{C} 40$ concrete the overstress hit a value close to $200 \%$, Table 4 , inducing, in this way, the material yielding.

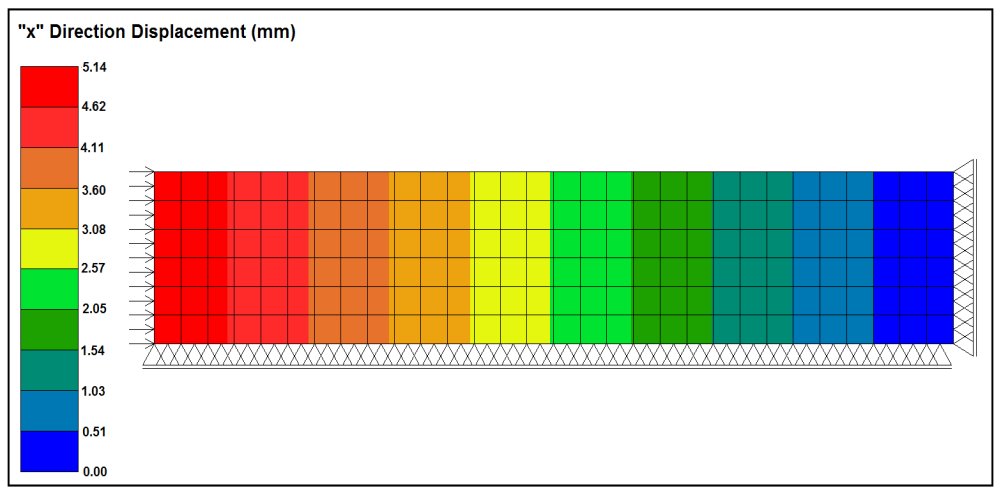

Figure 10. Field of creep longitudinal displacements: Day 860 - Case 1.

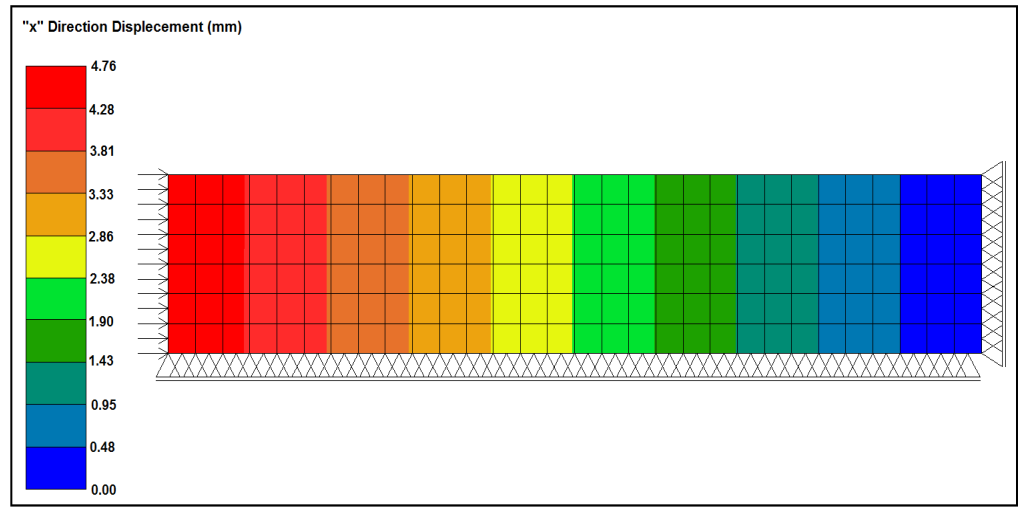

Figure 11. Field of creep longitudinal displacements: Day 379 - Case 11.

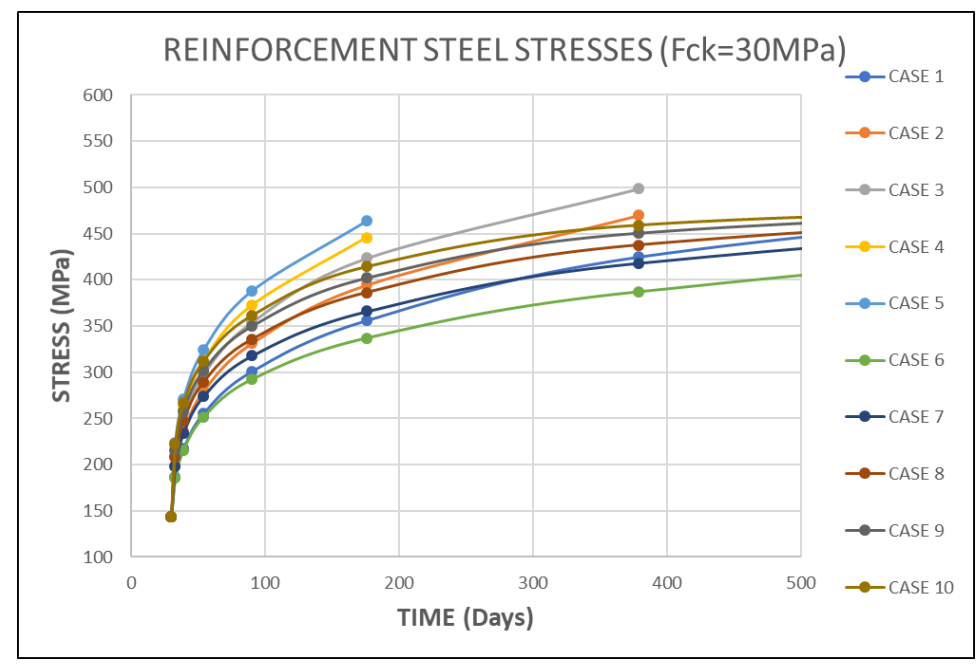

Figure 12. Stresses evolution on the reinforcement bars - C30 Concrete. 


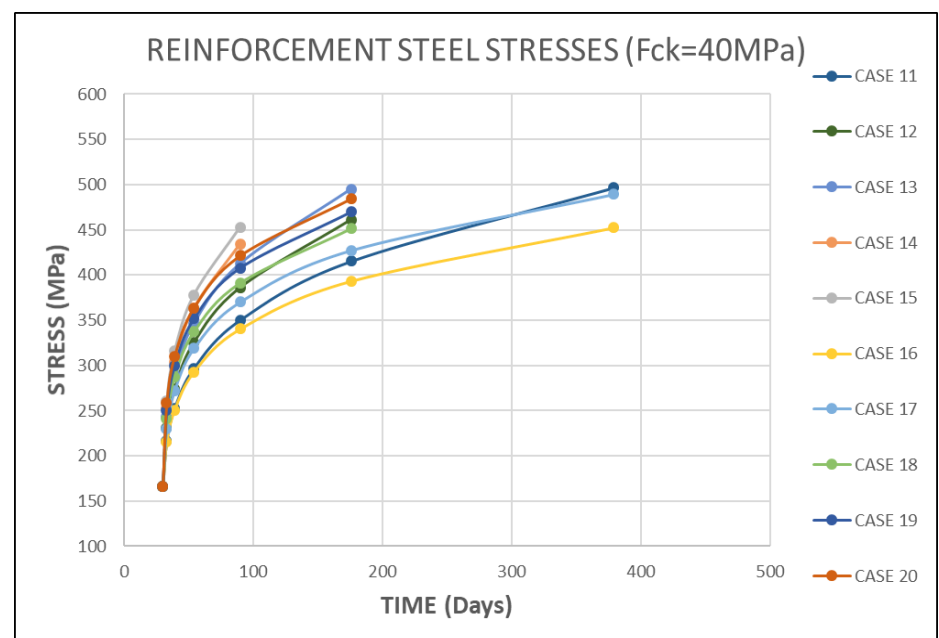

Figure 13. Stresses evolution on the reinforcement bars - C40 Concrete.

Table 4. Stresses on the reinforcement.

\begin{tabular}{ccccc}
\hline \multirow{2}{*}{ Cases } & & Reinforcement stresses (MPa) & & \multirow{2}{*}{ Final age (days) } \\
\cline { 2 - 4 } 1 & Immediate & Creep (90 days) & Final & 860 \\
\hline 2 & 143 & 301 & 499 & 379 \\
\hline 3 & 143 & 331 & 470 & 379 \\
\hline 4 & 143 & 354 & 498 & 176 \\
\hline 5 & 143 & 372 & 446 & 2000 \\
\hline 6 & 143 & 388 & 464 & 2000 \\
\hline 7 & 143 & 292 & 470 & 2000 \\
\hline 8 & 143 & 318 & 477 & 2000 \\
\hline 9 & 143 & 336 & 479 & 2000 \\
\hline 10 & 143 & 350 & 481 & 379 \\
\hline 11 & 143 & 361 & 482 & 176 \\
\hline 12 & 166 & 350 & 496 & 176 \\
\hline 13 & 166 & 386 & 495 & 90 \\
\hline 14 & 166 & 413 & 434 & 90 \\
\hline 15 & 166 & 434 & 453 & 379 \\
\hline 16 & 166 & 453 & 452 & 379 \\
\hline 17 & 166 & 340 & 489 & 176 \\
\hline 18 & 166 & 370 & 451 & 176 \\
\hline 19 & 166 & 391 & 484 & 176 \\
\hline
\end{tabular}

Although the observation time of the phenomenon discussed in this paper was fixed, at first, up to 2000 days of concrete age, due the precocity of the reinforcement bars steel yielding and the consequent lost of the column stability, as was already commented in the upper paragraph, in some studied cases the time-displacement curves and the timestresses curves are being broken up. Due to that reason the 90 days of the age of concrete was considered as a reference for the relevant parameters' comparative analysis for all cases. Such age corresponds to the smallest among those one at which the steel yielding of all studied cases already has been triggered.

According to the obtained results the smallest creep displacement at the age of reference was about $2.1 \mathrm{~mm}$, registered for case 6 , Table 2, which refers itself to the smallest temperature, corresponding to 1.05 times the displacement recorded at the instant of loading. The largest one was about $4.1 \mathrm{~mm}$, registered for case 15 , which concerns itself to the highest temperature and corresponds to 1.7 times the displacement pointed at the instant of loading.

From more detailed analysis referring to C30 concrete, over the set of curves associated to moisture content by $40 \%$, namely cases 1, 2, 3, 4 and 5, presented in Figure 8, it may be noted that as higher the temperature as higher the creep 
displacements. Nevertheless, for all cases of this group, the creep displacements after the phenomenon stabilization, present, in practice, similar magnitudes. In the same way, the set of curves associated to cases $6,7,8,9$ and 10, referring to the moisture content by $60 \%$, exhibits a similar trend.

As to be expected from the fact that reinforcement bars stresses and the creep strains developed themselves on a similar pattern, the overstress was more significant and, therefore, the steel yielding was hit, as earlier as higher the temperature.

The gotten results indicate that the creep strains may promote the stress relief on the mass of concrete, Figure 14 and 15 and in some cases, the stresses fields stabilized themselves at 2000 days of concrete age according the aspect illustrated in Figure 16. In other cases, the relieving process was stopped prematurely, due to the yielding of reinforcement steel bars. The lowest stress relief at the reference age was about 4,7\% and 4\%, registered for cases 6 and 16 , that are referred, to the lowest temperature, while, the largest one was about $8 \%$ and $7 \%$, verified to the cases 5 and 15 , referring to the highest temperature. However, it is worthwhile of note that was recorded stress relief of about $14 \%$ for cases 8,9 and 10 , when the stationary condition was reached.

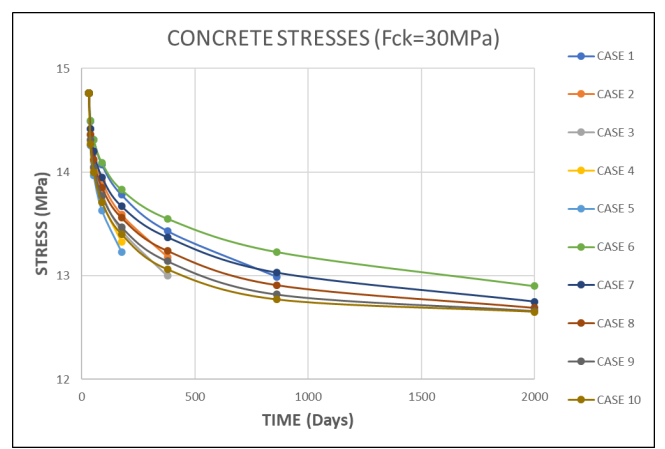

Figure 14. C30 Concrete stresses evolution by creep.

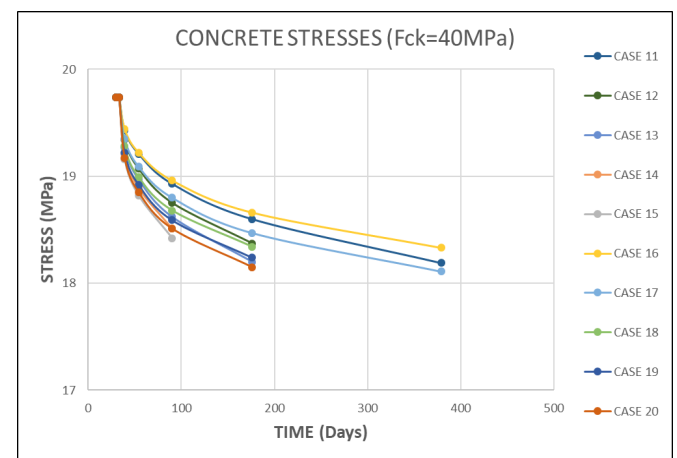

Figure 15. C40 Concrete stresses evolution by creep.

It was noticed, indeed, from the comparison between Figures 7 and 16, that the creep strains have intensified the stresses disturbance upon the mass of concrete over the region close to the top of column.

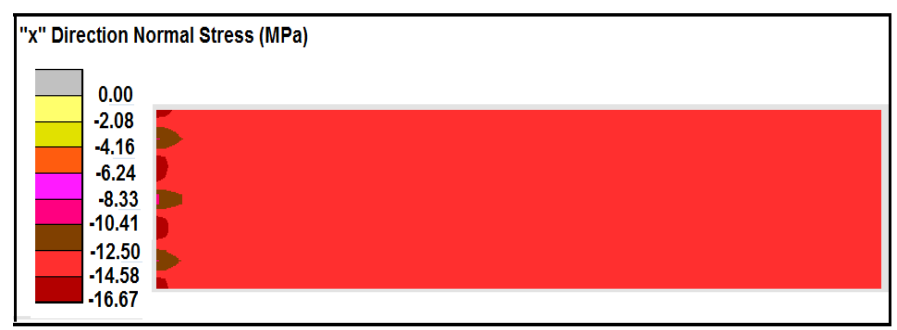

Figure 16. Field of the normal stresses on the mass of concrete: Day 860 - Case 1. 


\section{CONCLUSIONS}

This work refers itself to the analysis of the temperature effects upon creep strains on reinforced concrete structural members based on a State Model from a non-linear orthotropic calculus framework and the finite element approximation.

Twenty cases involving thin-walled columns, differentiated among themselves by the temperature, by the concrete strength and by the moisture content, were studied.

The obtained results showed that, already at 2000 days from concrete cast, the creep displacement, virtually, reaches the stationary condition.

The analysis performed from the acquired results pointed out the occurrence of stresses increase on the reinforcement steel bars as it was reported in [14], that, especially for those cases referring to the highest temperature, it culminated to the material yielding condition, as reported in [13].

Because the yielding phenomenon commented in the last paragraph has occurred and, in this way, the column lost its structural stability, already, at 90 days from the concrete cast, even before the concrete creep strains had reached the stationary stage, such age was considered as the reference instant to the parameters comparative analysis performed in this work.

According to the obtained results, the creep displacement magnitudes at the reference age were as more pronounced as higher the temperature although, for those cases for which the deformation process was maintained up to the creep phenomenon stability, the final displacement values showed themselves temperature independent.

As a matter of fact, if the comparative analysis of the parameters corresponds to that age from which the steel yielding has triggered and that such an instant is earlier than the creep stabilization, the considered magnitudes of the concrete creep displacements in such a analysis are much lower than they would be if the steel yielding phenomenon had not occur.

From the acquired results it was noted the occurrence of stresses relief in the mass of concrete that, at the referring age, was as greater as higher the temperature, as it would be to expect.

\section{ACKNOWLEDGEMENTS}

This report is part of a research work on the numerical simulation of the creep strains on reinforced concrete members supported by the Fundação Coordenação de Aperfeiçoamento de Pessoal de Nível Superior - CAPES and by the Pró-Reitoria de Pesquisa da Universidade Federal do Rio Grande do Norte - UFRN. Their support is gratefully acknowledged.

\section{REFERENCES}

[1] A. M. Neville, Properties of Concrete. London, UK: Pearson, Prentice Hall, 2004.

[2] J. K. Wight and J. G. McGregor, Reinforced Concrete-Mechanics \& Design. Boston, MA: Pearson, 2012.

[3] E. L. Madureira and L. A. Paiva, "Fresh concrete consistency effect on thin-walled columns creep phenomenon," IBRACON Struct. Mater. J., vol. 11, no. 3, pp. 644-651, May/Jun. 2018, http://dx.doi.org/10.1590/s1983-41952018000300012.

[4] Associação Brasileira de Normas Técnicas NBR 6118: Projeto de Estruturas de Concreto - Procedimento. Rio de Janeiro, RJ, Brasil: ABNT, 2014.

[5] A. Kawano and R. F. Warner, "Model formulations for numerical creep calculations for concrete," J Struct. Eng., vol. 122, no. 3, pp. 284-290, Mar. 1996. http://dx.doi.org/10.1061/(ASCE)0733-9445(1996)122:3(284).

[6] P. M. Pimenta and H. C. Santos, “Análise e Retro-análise de Estruturas de Concreto Sujeitas à Deformação Lenta,” in IV Simpósio EPUSP sobre Estruturas de Concreto. São Paulo, SP, Brasil, Aug. 2000.

[7] H. G. Kwak and F. C. Filippou, Finite Elements Analysis of Reinforced Concrete Structures Under Monotonic Loads (Report UCB/SEMM-90/14). Berkeley, CA: University of California, 1990.

[8] E. Hognestad, A Study of Combined Bending and Axial Load in Reinforced Concrete Members. (Bolletin n. 399, Vol. 49, no. 22). Urbana, Illinóis: University of Illinois, Engineering Experiment Station, 1951.

[9] H. B. Kupfer and K. H. Gerstle, "Behaviour of Concrete under Biaxial Stresses," J Eng Mech, vol. 99, no. 4, pp. 853-866, Aug. 1973.

[10] E. L. Madureira, "Simulação numérica do comportamento mecânico de elementos de concreto armado afetados pela reação álcaliagregado,” Ph.D. dissertation, Dept. Eng. Civil, Univ. Fed. Pernambuco, Recife, PE, 2007.

[11] R. L. S. Pitangueira and E. Parente Jr, NLPOS - Programa para Visualização de Resultados de Analises Não Lineares de Modelos Bidimensionais de Elementos Finitos. Versão 1.0, Rio de Janeiro: DEC/PUC-Rio, 1997. 
[12] E. L. Madureira and A. L. A. Silva, PROJECT1 - Programa para Visualização de Campos de Tensões Resultantes de Analises Não Lineares de Modelos Bidimensionais de Elementos Finitos. Versão 1.0, Rio Grande do Norte: DEC/UFRN, 2013.

[13] E. L. Madureira, T. M. Siqueira, and E. C. Rodrigues, "Creep strains on reinforced concrete columns," IBRACON Struct. Mater. J., vol. 6, no. 4, pp. 537-560, 2013., http://dx.doi.org/10.1590/S1983-41952013000400003.

[14] L. T. Kataota, M. A. S. Machado, and T. N. Bittencourt, "Análise numérica da transferência de carga do concreto para a armadura em pilares de concreto armado devida à fluência e retração," in IBRACON, Fortaleza: IBRACON, 2010.

[15] C. S. Desai and H. J. Siriwardance, Constitutive Laws for Engineering Materials. Englewood Cliffs, NJ: Prentice Hall, 1972.

Author contributions: ELM, BVCF conceptualization, conceptualization, formal analysis, methodology, writing; BVCF: data curation.

Editors: Bernardo Tutikian, José Luiz Antunes de Oliveira e Sousa, Guilherme Aris Parsekian. 